\title{
Sistem Pendukung Keputusan Penentuan Dosen Pembimbing Dan Bimbingan Thesis Secara Online Pada Program Pascasarjana Universitas Galuh
}

\author{
Nono Sudarsono ${ }^{1}$, Harin Sanditha Rahmawati ${ }^{2}$ \\ ${ }^{1,2}$ Jurusan Teknik Informatika \\ ${ }^{3}$ STMIK Tasikmalaya; Jl. R.E. Martadinata 272 A Tasikmalaya, (0265) 310830 \\ e-mail: ${ }^{1}$ nonoznonozsudar@gmail.com, ${ }^{2}$ harinsanditha@gmail.com
}

\begin{abstract}
Abstrak
Proses penentuan dosen pembimbing diawali dari proses pengajuan judul thesis yang diajukan terlebih dahulu oleh Mahasiswa kepada Bagian Prodi. Pada proses pemiihan judul thesis yang dilakukan oleh Bagian Prodi belum optimal, karena memerlukan banyak waktu, biaya yang tidak sedikit bahkan cukup menguras tenaga karena banyaknya mahasiswa dalam mengajukan judul thesis. Selain itu, proses penentuan pembimbing yang dilakukan oleh bagian prodi Program Pascasarjana di Universitas Galuh Ciamis belum menggunakan metode perhitungan dalam pengambilan keputusan yang dikhawatirkan terjadinya penilaian secara subjektif pada proses pemilihan tersebut. Dalam penelitian ini dirancang sebuah sistem pendukung keputusan yang dapat mengoptimalkan proses penentuan dosen pembimbing dan bimbingan secara online dengan pengembangan sistem menggunakan metode SDLC dan perancangan database menggunakan ERD, serta diimplementasikan dengan bahasa pemrograman PHP dan penyimpanan database dengan MySQL. Metode keputusan yang digunakan adalah Analytical Hierarchy Process untuk perhitungan bobot prioritas dan konsistensi kriteria, sedangkan Technique For Order Preference By Similarity To Ideal Solution untuk menghitung nilai preferensi dan prioritas penentuan dosen pembimbing.Hasil yang dicapai dari sistem pendukung keputusan ini dapat membantu proses pemilihan dosen pembimbing menjadi lebih cepat, menghasilkan nilai $\mathrm{CR}=0,07$ yang menunjukan konsistensi nilai perbandingan kriteria yang diberikan dan mampu menghasilkan dosen pembimbing dalam melakukan bimbingan thesis secara online.
\end{abstract}

Kata Kunci - AHP, Penentuan Dosen Pembimbing, Sistem Pendukung Keputusan, TOPSIS

\begin{abstract}
The process of determining the supervisor starts with the process of submitting a thesis title submitted in advance by the student to the Study Program Department. In the thesis selection process carried out by the Study Program Section is not optimal, because it requires a lot of time, the cost is not small or even quite draining because of the many students in submitting the thesis title. In addition, the process of determining counselors carried out by the Postgraduate Program study program at Galuh Ciamis University has not used the calculation method in making decisions that are feared to have subjective judgments on the selection process. In this research, a decision support system is designed that can optimize the process of determining the supervisor and online guidance by developing the system using the SDLC method and database design using ERD, and implemented with the PHP programming language and database storage with MYSQL. The decision method used is the Analytical Hierarchy Process for calculating priority weights and consistency criteria, while Technique For Order Preference By Similarity To Ideal Solution for calculating the preference and priority values of the supervisor.The results achieved from this decision support system can help the process of selecting supervisors to be faster, resulting in a CR value of 0.05 which shows the consistency of the value comparison of the criteria provided and is able to produce supervisors in conducting their final assignments online.
\end{abstract}

Keywords - AHP, Decision Support Systems, Determining the Supervisor, TOPSIS 


\section{PENDAHULUAN}

Bimbingan thesis merupakan salah satu proses yang perlu dilalui oleh mahasiswa S2 program Pascasarjana di Universitas Galuh Ciamis. Thesis merupakan karya akhir mahasiswa sebagai syarat penyelesaian pendidikan bentuk perwujudan karya mahasiswa setelah menjalani proses program Pascasarjana di Universitas Galuh Ciamis. Mahasiswa harus melakukan proses penelitian atau riset untuk mencapai tujuan dalam menyelesaikan thesisnya.

Dalam hal ini terdapat kendala yang menjadi penyebab terhadap kelulusan mahasiswa program pascasarjana dimana dalam proses bimbingan seperti jadwal yang berbeda antara dosen dan mahasiswa sehingga proses bimbingan dapat terbengkalai, kesulitan bagi mahasiswa dan dosen untuk mengadakan pertemuan dalam setiap bimbingan untuk tiap bab per babnya dikarenaka dosen sangat sulit untuk ditemui, kebanyakan dosen dengan identitas pejabat sering melakukan jam kerja diluar lingkungan kampus. kadang kala prosedur standar seperti pencatatan form bimbingan tidak terorganisasi dengan baik dan juga mahasiswa diharuskan untuk selalu berada di kampus untuk mendapatkan informasi terbaru mengenai proses bimbingan thesis sehingga akan berdampak pada kelulusan sidang menjadi kurang tepat waktu dan akurat.

Berdasarkan data yang diperoleh dari program Pascasarjana di Universitas Galuh Ciamis, dapat diketahui diantaranya dari kondisi keterlambatan kelulusan mahasiswa. Seperti terlihat pada tabel dibawah ini mengenai prosentase Jumlah Keterlambatan kelulusan Mahasiswa program Pascasarjana pada tahun 2014 - 2019.

Tabel 1. Prosentase Jumlah kelulusan Mahasiswa Program Pascasarjana

\begin{tabular}{|c|c|c|c|c|c|}
\hline $\begin{array}{c}\text { Tahun } \\
\text { Masuk }\end{array}$ & $\begin{array}{c}\text { Jumlah } \\
\text { Mahasiswa } \\
\text { Masuk }\end{array}$ & $\begin{array}{c}\text { Jumlah } \\
\text { Lulusan }\end{array}$ & $\begin{array}{c}\text { Jumlah } \\
\text { Keterlambatan } \\
\text { kelulusan } \\
\text { Mahasiswa }\end{array}$ & $\begin{array}{c}\text { Prosentase } \\
\text { Keterlambatan } \\
\text { dari jumlah } \\
\text { lulusan }\end{array}$ & $\begin{array}{c}\text { Prosentase Tidak } \\
\text { Keterlambatan } \\
\text { dari jumlah } \\
\text { lulusan }\end{array}$ \\
\hline 2012 & 216 & 22014 & 22 & $13,25 \%$ & $86,75 \%$ \\
\hline 2013 & 372 & 2015 & 24 & $7,72 \%$ & $92,28 \%$ \\
\hline 2014 & 408 & 2016 & 15 & $4,57 \%$ & $95,43 \%$ \\
\hline 2015 & 278 & 198 & 17 & $8,59 \%$ & $91,41 \%$ \\
\hline 2016 & 335 & 242 & 2618 & $10,74 \%$ & $89,26 \%$ \\
\hline 2017 & 454 & 232 & 38 & $16,37 \%$ & $83,63 \%$ \\
\hline
\end{tabular}

Berdasarkan tabel 1.1, diketahui prosentase jumlah keterlambatan kelulusan mahasiswa yang terhitung dari tahun 2014 hingga tahun 2015 mengalami kenaikan. Begitu juga pada jumlah keterlambatan kelulusan mahasiswa, untuk tahun 2015 hingga tahun 2016 prosentase jumlah keterlambatan kelulusan mahasiswa mengalami penurunan. Namun pada tahun 2017 mengalami kenaikan kembali hingga 8,59\%. Dalam penentuan dosen pembimbing, mahasiswa dapat mengusulkan dosen mana yang ingin dijadikan pembimbing, tetapi keputusan akan tetap pada rapat dosen. Dengan penentuan pembimbing thesis yang masih manual ini, biasanya memerlukan waktu yang cukup lama. Karena harus menentukan dosen mana yang cocok 
dengan judul dan tugas akhir dari mahasiswa yang cukup banyak. Dalam penentuan pembimbing thesis, dosen juga harus membaca setiap judul untuk benar-benar mencocokan dengan keahlian dosen dan pengalaman dosen dalam membimbing. Rapat dapat memakan waktu sehari kerja untuk menentukan pembimbing untuk lebih dari 50 mahasiswa, ini sangat tidak efisien.

Untuk mengatasi permasalahan tersebut, perlu dibuat sistem informasi bimbingan thesis, yang dapat membantu menyelesaikan permasalahan yang dihadapi dalam proses bimbingan thesis di Program Pascasarjana Universitas Galuh Ciamis sehingga dapat bekerja layaknya bimbingan thesis secara tatap muka dengan perantara sistem. Aplikasi ini diharapkan akan memberikan kemudahan baik bagi para mahasiswa maupun dosen pembimbing untuk melakukan bimbingan thesis sehingga dapat meminimalisir proses pembuatan thesis akibat perbedaan jadwal kesibukan antara mahasiswa dan dosen pembimbing. Dengan aplikasi ini mahasiswa dan dosen pembimbing diharapkan tetap dapat melakukan bimbingan tanpa harus mencocokkan jadwal atau bertatap muka. Dalam hal ini, peran dosen pembimbing juga menjadi faktor yang ikut menentukan dalam proses penyelesaian thesis tersebut.

Sistem pendukung keputusan adalah suatu sistem informasi untuk membantu manajer untuk proses pengambilan keputusan dalam menangani berbagai permasalahan yang tidak terstruktur agar lebih efektif dengan menggunakan model-model analisis dan data yang telah ditentukan [1]. Oleh karena itu perlu dibuat sebuah sistem pendukung keputusan dalam penentuan dosen pembimbing thesis. Untuk menentukan dosen mana yang cocok dengan judul mahasiswa. Keputusan ini akan diambil berdasarkan beberapa variable yang akan dapat membuat keakuratan dalam pemilihan dosen pembimbing. Serta yang paling penting dalam sistem ini yaitu membuat penentuan dosen pembimbing lebih cepat dan efisien. Maka salah satu solusi yang dapat digunakan adalah dengan melakukan kombinasi metode AHP dan TOPSIS dipilih dengan alasan metode AHP memiliki kelebihan berdasar pada matriks perbandingan pasangan dan melakukan analisis konsistensi. Sedangkan metode TOPSIS dapat menyelesaikan pengambilan keputusan secara praktis, karena konsepnya sederhana dan mudah dipahami, komputasinya efisien, serta memiliki kemampuan mengukur kinerja relatif dari alternatifalternatif keputusan [2].

Dengan diterapkannya sistem pendukung keputusan dalam penentuan dosen pembimbing, diharapkan dapat meminimalisir permasalahan-permasalahan seperti yang sudah dipaparkan. Dengan output berupa program aplikasi yang menerapkan metode AHP (Analytical Hierarchy Process) dan TOPSIS (Technique For Order Preference By Similarity To Ideal Solution) untuk menghasilkan rating keputusan dalam penyeleksian alternatif terbaik guna mencapai hasil yang optimal serta pembuatan laporan yang lebih efektif.

\section{METODE PENELITIAN}

Metode pengembangan Sistem Pendukung Keputusan Penentuan Dosen Pembimbing dan Bimbingan Thesis Secara Online di Program Pascasarjana Universitas Galuh Ciamis menggunakan Metode System Development Life Cycle (SDLC). Adapun model yang digunakan dalam penulisan skripsi ini yaitu model Waterfall. Aktifitas yang terdapat di dalam waterfall tampak pada gambar berikut : 


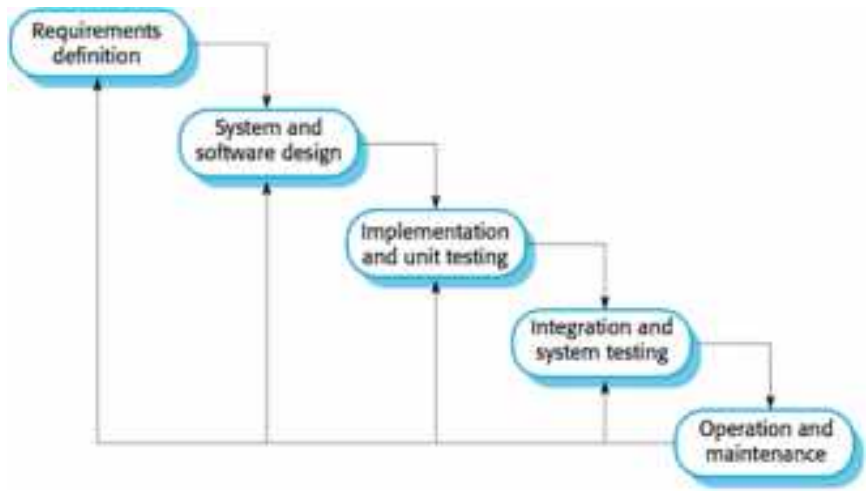

Gambar 1. Tahapan Waterfall [3]

Pada skema waterfall terdapat beberapa tahapan. Yaitu sebagai berikut :

\subsection{Requirements Analysis and Definition}

Dalam tahapan ini penulis mengumpulkan kebutuhan secara lengkap kemudian dianalisis dan didefinisikan kebutuhan perangkat lunak yang akan dibangun, kegiatan yang dilakukan diantaranya mempelajari sistem yang lama, menganalisis prosedur penentuan dosen pembimbing dan bimbingan thesis, analisis data menggunakan metode AHP dan TOPSIS serta analisis kebutuhan pengguna (User Requirement).

\subsection{System and Software Design}

Fase selanjutnya yang dilakukan adalah perancangan sistem dan aplikasi, kegiatan yang dilakukan dalam tahapan ini diantaranya :

a. Melakukan perancangan antar muka input-output.

b. Membuat perancangan basis data.

c. Membuat pemodelan sistem menggunakan Teknik UML (Unified Modeling Language). Rosa A.S dan M.Shalahudin [4], Pada UML terdiri dari 13 Macam diagram yang dikelompokkan dalam 3 kategori. Dalam proses pengembangan perangkat lunak penggunaan UML dapat digunakan pada tahap analisis dan desain. Namun, untuk membedakan tahap analisis dan desain, diputuskan UML digunakan pada tahap desain walaupun sebenarnya dapat membantu dalam menganalisis kebutuhan. Dalam proses pembangunannya UML bersifat independen terhadap bahasa pemodelan visual. Ada 13 Macam diagram UML yang dikelompokan ke dalam 3 kategori. Lihat gambar berikut :

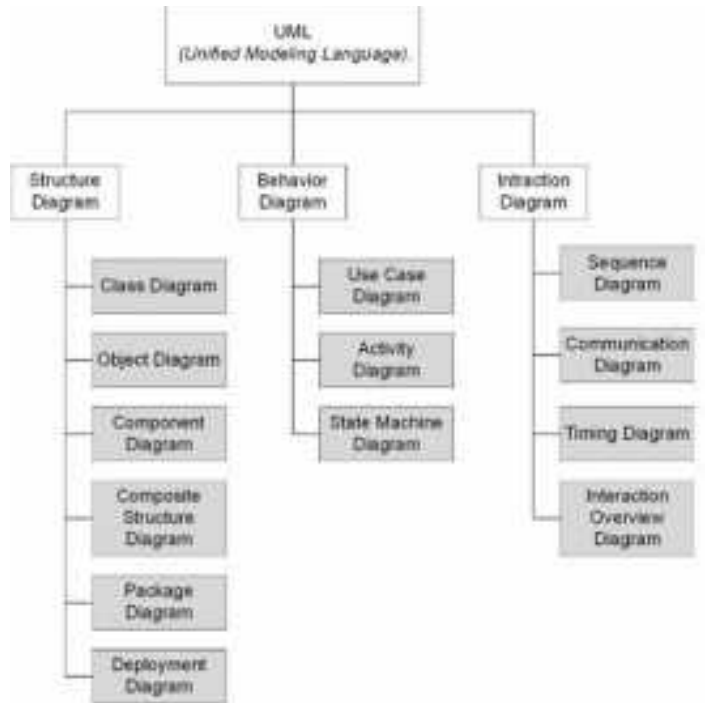

Gambar 2. Kategori UML (Unified Modeling Language) [4]. 


\subsection{Implementation and Unit Testing}

Dari fase desain perangkat lunak selanjutnya melakukan fase implementasi dan pengujian unit. Pengujian melibatkan verifikasi bahwa setiap unit program memenuhi spesifikasinya, kegiatan yang dilakukan diantaranya :

a. Implementasi antar muka.

b. Implementasi hardware dan software.

c. Pengujian sub-sub program.

d. Dalam tahapan ini akan diuraikan secara rinci pada BAB V.

2.4. Integration and System Testing

Dari fase implementasi dan pengujian unit kemudian melakukan fase integrasi dan pengujian sistem. Unit program digabung dan diuji sebagai sebuah sistem lengkap untuk memastikan apakah sesuai dengan kebutuhan perangkat lunak atau tidak, teknik pengujian yang dilakukan pada penelitian ini menggunakan pengujian black box. Dalam pengujian black box penulis melakukan pengujian validasi dan fungsional terhadap form login, form data dosen, form pengajuan, form perbandingan kriteria, form penilaian, dan form perhitungan AHP-TOPSIS.

\subsection{Operation and Maintenance}

Setelah melakukan fase-fase tersebut fase selanjutnya yaitu fase pengoperasian dan pemeliharaan sistem, pemeliharaan melibatkan penanganan kesalahan yang tidak ditemukan pada tahapan-tahapan sebelumnya, meningkatkan implementasi dari unit sistem, dan meningkatkan layanan sistem sebagai kebutuhan baru.

\section{HASIL DAN PEMBAHASAN}

\subsection{Analisis Pemecahan Masalah Menggunakan Metode AHP-TOPSIS}

Perhitungan metode Analytical Hierarchy Process (AHP) digunakan untuk menetakan tiap-tiap bobot pada kriteria, serta menetukan rasio konsistensi diterima atau tidaknya setiap kriteria. Sedangkan metode TOPSIS digunakan sebagai perangkingan penentuan dosen pembimbing di Program Pascasarjana Universitas Galuh Ciamis.

\subsubsection{Perhitungan Metode AHP}

\section{Penentuan Kriteria}

Berdasarkan data yang diperoleh dari Program Pascasarjana Universitas Galuh Ciamis kriteria yang diperlukan dalam penentuan dosen pembimbing antara lain :

Tabel 2. Kriteria Penentuan Dosen Pembimbing

\begin{tabular}{|l|l|l|}
\hline Kode & Kriteria & Atribut \\
\hline C1 & Absen Dosen & Benefit \\
\hline C2 & Status Ikatan Kerja Dosen & Benefit \\
\hline C3 & Jabatan Akademik Dosen & Cost \\
\hline C4 & Kuota Bimbingan Mahasiswa & Benefit \\
\hline C5 & Durasi Bimbingan per Minggu & Benefit \\
\hline C6 & Konsentrasi Jurusan & Benefit \\
\hline C7 & Keahlian Matakuliah yang Ditempuh & Benefit \\
\hline
\end{tabular}

Tahap selanjutnya yaitu menentukan nilai untuk setiap faktor atau kriteria, berikut penilaian sub kriteria yang dapat dilihat pada tabel 3: 
Tabel 3. Nilai Sub Kriteria

\begin{tabular}{|c|c|c|}
\hline Kriteria & Sub Kriteria & Nilai \\
\hline \multirow{3}{*}{ Absen Dosen } & 16 & 10 \\
\hline & $12-15$ & 5 \\
\hline & $7-11$ & 3 \\
\hline \multirow{2}{*}{$\begin{array}{c}\text { Status Ikatan } \\
\text { Kerja Dosen }\end{array}$} & Tetap & 10 \\
\hline & Tidak Tetap & 5 \\
\hline \multirow{4}{*}{ Jabatan Dosen } & Rektor & 5 \\
\hline & Ketua Bagian & 3 \\
\hline & Wakil Rektor & 3 \\
\hline & Tenaga Pengajar & 10 \\
\hline \multirow{5}{*}{$\begin{array}{c}\text { Kuota } \\
\text { Bimbingan } \\
\text { Mahasiswa }\end{array}$} & $1-5$ orang & 3 \\
\hline & $6-8$ orang & 5 \\
\hline & $9-12$ orang & 7 \\
\hline & $13-18$ orang & 10 \\
\hline & $19-25$ orang & 15 \\
\hline \multirow{3}{*}{$\begin{array}{c}\text { Durasi } \\
\text { Bimbingan per } \\
\text { Minggu }\end{array}$} & 1 kali / Minggu & 3 \\
\hline & 2 kali / Minggu & 5 \\
\hline & 3 kali / Minggu & 10 \\
\hline \multirow{10}{*}{$\begin{array}{c}\text { Konsentrasi } \\
\text { Jurusan }\end{array}$} & Administrasi Sistem Pendidikan & 10 \\
\hline & Administrasi Pendidikan Olahraga & 3 \\
\hline & Administrasi Pendidikan Dasar & 5 \\
\hline & Administrasi Pendidikan Luar Sekolah & 5 \\
\hline & Manajemen Sumberdaya Manusia & 6 \\
\hline & Manajemen Pemerintahan & 5 \\
\hline & Manajemen Pemasaran & 7 \\
\hline & Hukum Pidana & 8 \\
\hline & Hukum Tata Negara & 10 \\
\hline & Hukum Perdata & 6 \\
\hline \multirow{14}{*}{$\begin{array}{c}\text { Keahlian } \\
\text { Matakuliah } \\
\text { yang Ditempuh }\end{array}$} & Pengantar Ilmu Sosial dan Kepemimpinan Pendidikan & 3 \\
\hline & Statistika dan Matematika Ekonomi & 4 \\
\hline & Kimia Organik dan Kimia Anorganik & 5 \\
\hline & Etika Profesi dan Keguruan Manajemen Keuangan & 6 \\
\hline & Pengelolaan Pendidikan dan Reading For General Purpose & 7 \\
\hline & Kapita Selekta Kependidikan dan Ilmu Pendidikan & 8 \\
\hline & Manajemen Strategi dan Manajemen Pemasaran & 10 \\
\hline & Sistem Informasi dan Manajemen Metodologi Penelitian & 8 \\
\hline & Manajemen Keuangan dan Statistika Terapan & 6 \\
\hline & Manajemen Operasional dan Filsafat Ilmu & 4 \\
\hline & Filsafat Ilmu Hukum dan Tindak Pidana Medis & 6 \\
\hline & Hukum Tata Lingkungan dan Sengketa Hukum Pemilu & 5 \\
\hline & Hukum Bisnis Internasional dan Hukum Perbankan & 8 \\
\hline & Hukum Ekonomi Hukum dan Tidak Pidana Korupsi & 10 \\
\hline
\end{tabular}


2. Penentuan Bobot Prioritas dan Konsistensi Kriteria

Langkah-langkah yang harus dilakukan dalam menentukan prioritas kriteria adalah sebagai berikut :

a. Membuat perbandingan matriks berpasangan indikator yang digunakan, berdasarkan kepentingan relatif dari masing-masing indikator. Berikut matriks perbandingan berpasangan kriteria sistem pendukung keputusan penentuan dosen pembimbing dapat dilihat pada tabel 4 .

Tabel 4. Matriks Perbandingan Berpasangan

\begin{tabular}{|c|c|c|c|c|c|c|c|}
\hline Kode & C1 & C2 & C3 & C4 & C5 & C6 & C7 \\
\hline C1 & 1 & 2 & 2 & 3 & 2 & 3 & 2 \\
\hline C2 & 0,33 & 1 & 2 & 2 & 2 & 2 & 3 \\
\hline C3 & 0,5 & 0,5 & 1 & 2 & 4 & 2 & 3 \\
\hline C4 & 0,33 & 0,33 & 0,5 & 1 & 2 & 3 & 2 \\
\hline C5 & 0,5 & 0,5 & 0,33 & 0,5 & 1 & 2 & 2 \\
\hline C6 & 0,33 & 0,5 & 0,5 & 0,33 & 0,5 & 1 & 3 \\
\hline C7 & 0,5 & 0,333 & 0,33 & 0,5 & 0,5 & 0,33 & 1 \\
\hline
\end{tabular}

b. Mengitung matriks normalisasi dengan membagi elemen pada setiap kolom dengan total perkolom yang sesuai.

Tabel 5. Matriks Nilai Normalisasi

\begin{tabular}{|c|c|c|c|c|c|c|c|}
\hline Kode & C1 & C2 & C3 & C4 & C5 & C6 & C7 \\
\hline C1 & 0,286 & 0,387 & 0,300 & 0,321 & 0,167 & 0,225 & 0,125 \\
\hline C2 & 0,095 & 0,194 & 0,300 & 0,214 & 0,167 & 0,150 & 0,188 \\
\hline C3 & 0,143 & 0,097 & 0,150 & 0,214 & 0,333 & 0,150 & 0,188 \\
\hline C4 & 0,095 & 0,065 & 0,075 & 0,107 & 0,167 & 0,225 & 0,125 \\
\hline C5 & 0,143 & 0,097 & 0,050 & 0,054 & 0,083 & 0,150 & 0,125 \\
\hline C6 & 0,095 & 0,097 & 0,075 & 0,036 & 0,042 & 0,075 & 0,188 \\
\hline C7 & 0,143 & 0,065 & 0,050 & 0,054 & 0,042 & 0,025 & 0,063 \\
\hline
\end{tabular}

c. Mencari rata-rata untuk setiap baris pada matriks normalisasi, sehingga didapatkan bobot (W) dari masing-masing kriteria.

Tabel 6. Bobot Prioritas

\begin{tabular}{|c|c|c|c|c|c|c|c|}
\hline Kode & C1 & C2 & C3 & C4 & C5 & C6 & C7 \\
\hline Bobot $(\mathbf{W})$ & 0,259 & 0,187 & 0,182 & 0,123 & 0,100 & 0,087 & 0,063 \\
\hline
\end{tabular}

d. Uji konsistensi matriks

Uji konsistensi ini penting untuk mengecek apakah kita sudah benar (konsisten) memberikan nilai perbandingan pada setiap kriteria. Berikut langkah untuk menghitung konsistensi matriks:

1. Menghitung nilai CM (Consistency Measure)

Nilai CM (Consistency Measure) didapat dari hasil perkalian antara matriks perbandingan berpasangan pada tabel 4 dengan nilai bobot prioritas kriteria masing-masing baris pada tabel 6 .

Tabel 7. Nilai CM (Consistency Measure)

\begin{tabular}{|l|l|l|l|l|l|l|l|}
\hline Kode & C1 & C2 & C3 & C4 & C5 & C6 & C7 \\
\hline CM & 7,540 & 7,737 & 7,759 & 7,733 & 7,425 & 7,347 & 7,245 \\
\hline
\end{tabular}


2. Menghitung nilai $\mathrm{CI}$ (Consistency Index)

Nilai CI (Consistency Index) didapat dengan rumus :

$$
C I=\frac{\lambda \max -n}{n}
$$

LambdaMax adalah rata-rata dari CM (Consistency Measure), $n$ adalah jumlah kriteria (ukuran matriks) $=7$, sehingga $: C I=(7,541-7) /(7-1)=0,09$.

3. Mencari nilai RI (Ratio Index)

Berdasarkan teori Saaty Ratio Index sudah ditentukan nilainya berdasarkan ordo matriks (jumlah kriteria).

Tabel 8. Nilai RI (Ratio Index)

\begin{tabular}{|l|c|c|c|c|c|c|c|c|c|}
\hline Matriks & 1,2 & 3 & 4 & 5 & 6 & 7 & 8 & 9 & 10 \\
\hline RI & 0 & 0,58 & 0,90 & 1,12 & 1,24 & 1,32 & 1,41 & 1,45 & 1,49 \\
\hline
\end{tabular}

4. Menghitung nilai CR (Consistency Ratio)

$$
C R=\frac{C I}{R I}
$$

Menghitung CR (Consistency Ratio) didapat dari nilai CI dan RI, dengan cara $C I / R I=0,09$ / 1,32 $=0,07$. Untuk nilai $C R=0-0,1$ dianggap konsisten, jika lebih dari itu maka tidak konsisten [5]. Sehingga perbandingan yang diberikan untuk setiap kriteria pada penentuan dosen pembimbing sudah konsisten.

\subsubsection{Perhitungan Metode TOPSIS}

Dari perhitungan metode AHP maka didapat nilai bobot prioritas untuk setiap kriteria sebagai berikut :

Tabel 9. Nilai Bobot Prioritas

\begin{tabular}{|l|l|l|l|}
\hline Kode & Kriteria & Atribut & Bobot \\
\hline C1 & Absen Dosen & Benefit & 0,259 \\
\hline C2 & Status Ikatan Kerja Dosen & Benefit & 0,187 \\
\hline C3 & Jabatan Akademik Dosen & Cost & 0,182 \\
\hline C4 & Kuota Bimbingan Mahasiswa & Benefit & 0,123 \\
\hline C5 & Durasi Bimbingan per Minggu & Benefit & 0,100 \\
\hline C6 & Konsentrasi Jurusan & Benefit & 0,087 \\
\hline C7 & Keahlian Matakuliah yang Ditempuh & Benefit & 0,063 \\
\hline
\end{tabular}

Adapun langkah-langkah dalam menetukan keputusan dengan metode TOPSIS adalah sebagai berikut :

1. Menetukan matriks keputusan

Dalam studi kasus ini diambil 4 sampel data dosen proses penentuan dosen pembimbing dan akan diambil 2 dosen sebagai prioritas perangkingan. Berikut penilaian terhadap keempat dosen dapat dilihat pada tabel 10 .

Tabel 10. Ranking Kecocokan

\begin{tabular}{|l|c|c|c|c|c|c|c|}
\hline \multicolumn{1}{|c|}{ Nama } & C1 & C2 & C3 & C4 & C5 & C6 & \multicolumn{1}{c|}{ C7 } \\
\hline Tatang Parjaman & $12-15$ & tetap & $\begin{array}{l}\text { tenaga } \\
\text { pengajar }\end{array}$ & $\begin{array}{l}19-25 \\
\text { orang }\end{array}$ & $\begin{array}{c}2 \mathrm{x} \\
\text { /Minggu }\end{array}$ & $\begin{array}{l}\text { Adm Pend } \\
\text { Olahraga } \\
\text { dan } \\
\text { Manajemen } \\
\text { Keuangan }\end{array}$ \\
\hline Kusnandi & $7-11$ & tetap & $\begin{array}{l}\text { lektor } \\
\text { kepala }\end{array}$ & $\begin{array}{l}1-5 \\
\text { orang }\end{array}$ & $\begin{array}{c}1 \mathrm{x} \\
\text { /Minggu }\end{array}$ & $\begin{array}{c}\text { Adm Pend } \\
\text { Olahraga }\end{array}$ & $\begin{array}{l}\text { Pengelolaan } \\
\text { Pendidikan dan }\end{array}$ \\
\hline
\end{tabular}




\begin{tabular}{|c|c|c|c|c|c|c|l|}
\hline Nama & C1 & C2 & C3 & C4 & C5 & C6 & \multicolumn{1}{|c|}{ C7 } \\
\hline Awang Kustiawan & 16 & tetap & lektor & $\begin{array}{l}9-12 \\
\text { orang }\end{array}$ & $\begin{array}{c}2 \times \\
\text { /Minggu }\end{array}$ & $\begin{array}{l}\text { Adm Pend } \\
\text { Olahraga } \\
\text { General For } \\
\text { Purpose }\end{array}$ \\
\hline Maman Herman & 16 & tetap & $\begin{array}{l}\text { Kapita Selekta } \\
\text { Kependidikan } \\
\text { dan Ilmu } \\
\text { Pendidikan }\end{array}$ \\
\hline rektor & $\begin{array}{l}6-8 \\
\text { orang }\end{array}$ & $\begin{array}{l}\text { 1x } \\
\text { /Minggu }\end{array}$ & $\begin{array}{l}\text { Adm Pend } \\
\text { Luar Sekolah } \\
\text { Sosial dlmu } \\
\text { Kepemimpinan } \\
\text { Pendidikan }\end{array}$ \\
\hline
\end{tabular}

Tabel 11. Matriks Keputusan

\begin{tabular}{|l|l|l|l|l|l|l|l|}
\hline Nama & C1 & C2 & C3 & C4 & C5 & C6 & C7 \\
\hline Tatang Parjaman & 5 & 10 & 10 & 7 & 5 & 3 & 6 \\
\hline Kusnandi & 3 & 10 & 5 & 3 & 3 & 3 & 7 \\
\hline Awang Kustiawan & 10 & 10 & 3 & 15 & 5 & 3 & 8 \\
\hline Maman Herman & 10 & 10 & 3 & 15 & 3 & 5 & 3 \\
\hline
\end{tabular}

Dari tabel 11 dapat dibentuk matriks sebagai berikut :

$$
X=\begin{array}{ccccccc}
5 & 10 & 10 & 7 & 5 & 3 & 6 \\
3 & 10 & 5 & 3 & 3 & 3 & 7 \\
10 & 10 & 3 & 15 & 5 & 3 & 8 \\
10 & 10 & 3 & 15 & 3 & 5 & 3
\end{array}
$$

2. Menentukan matriks keputusan yang ternormalisasi

Perhitungan normalisasi matriks keputusan dapat dilakukan dengan menggunakan rumus dibawah ini :

$$
R_{i j}=\frac{x_{i j}}{=}=
$$

Maka menghasilkan matriks normalisasi pada tabel 12.

Tabel 12. Normalisasi Matriks

\begin{tabular}{|l|c|c|c|c|c|c|c|}
\hline Nama & C1 & C2 & C3 & C4 & C5 & C6 & C7 \\
\hline Tatang Parjaman & 0,180 & 0,258 & 0,257 & 0,156 & 0,167 & 0,105 & 0,236 \\
\hline Kusnandi & 0,108 & 0,258 & 0,129 & 0,067 & 0,100 & 0,105 & 0,275 \\
\hline Awang Kustiawan & 0,360 & 0,258 & 0,077 & 0,334 & 0,167 & 0,105 & 0,315 \\
\hline Maman Herman & 0,360 & 0,258 & 0,077 & 0,334 & 0,100 & 0,175 & 0,118 \\
\hline
\end{tabular}

Dari proses normalisasi diperoleh matriks $\mathrm{R}$ hasil normalisasi sebagai berikut :

$$
R=\begin{array}{lllllll}
0,180 & 0,258 & 0,257 & 0,156 & 0,167 & 0,105 & 0,236 \\
0,108 & 0,258 & 0,129 & 0,067 & 0,100 & 0,105 & 0,275 \\
0,360 & 0,258 & 0,077 & 0,334 & 0,167 & 0,105 & 0,315 \\
0,360 & 0,258 & 0,077 & 0,334 & 0,100 & 0,175 & 0,118
\end{array}
$$

3. Menentukan matriks normalisasi yang terbobot

Untuk membuat matrik normalisasi terbobot menggunakan rumus di bawah ini. 


$$
Y=\begin{array}{cccc}
y_{11} & y_{12} & \cdots & y_{1 j} \\
y_{21} & y_{22} & \cdots & y_{2 j} \\
\vdots & \vdots & \ddots & \vdots \\
y_{i 1} & y_{i 2} & \cdots & y_{i j}
\end{array} \text { untuk } Y_{i j}=W_{j} R_{i j}
$$

Dimana $W_{\mathrm{j}}$ merupakan bobot prioritas yang didapatkan dari tabel bobot prioritas pada tabel 9 Berikut matriks bobot prioritas kriteria :

$$
W=\left[\begin{array}{lllllll}
0,0279 & 0,0241 & 0,0468 & 0,0273 & 0,0335 & 0,0151 & 0,0074
\end{array}\right]
$$

Sehingga didapat hasil pembobotan matriks sebagai berikut :

Tabel 13. Pembobotan Matriks Ternormalisasi

\begin{tabular}{|l|c|c|c|c|c|c|c|}
\hline Nama & C1 & C2 & C3 & C4 & C5 & C6 & C7 \\
\hline $\begin{array}{l}\text { Tatang } \\
\text { Parjaman }\end{array}$ & 0,046 & 0,048 & 0,046 & 0,019 & 0,016 & 0,009 & 0,014 \\
\hline Kusnandi & 0,027 & 0,048 & 0,023 & 0,008 & 0,010 & 0,009 & 0,017 \\
\hline $\begin{array}{l}\text { Awang } \\
\text { Kustiawan }\end{array}$ & 0,093 & 0,048 & 0,014 & 0,040 & 0,016 & 0,009 & 0,019 \\
\hline $\begin{array}{l}\text { Maman } \\
\text { Herman }\end{array}$ & 0,093 & 0,048 & 0,014 & 0,040 & 0,010 & 0,015 & 0,007 \\
\hline
\end{tabular}

Dari tabel 13 dapat dibentuk matriks keputusan ternormalisasi dan terbobot sebagai berikut :

$$
Y=\begin{array}{lllllll}
0,046 & 0,048 & 0,046 & 0,019 & 0,016 & 0,009 & 0,014 \\
0,027 & 0,048 & 0,023 & 0,008 & 0,010 & 0,009 & 0,017 \\
0,093 & 0,048 & 0,014 & 0,040 & 0,016 & 0,009 & 0,019 \\
0,093 & 0,048 & 0,014 & 0,040 & 0,010 & 0,015 & 0,007
\end{array}
$$

4. Menentukan matriks solusi ideal positif $\left(A^{+}\right)$dan matriks solusi ideal negatif $\left(A^{-}\right)$.

a. Menentukan solusi ideal positif $\left(A^{+}\right)$

Untuk mencari solusi ideal ppositif digunakan rumus di bawah ini.

$$
\begin{gathered}
A^{+}=\left(y 1^{+}, y 2^{+}, \cdots, y j^{+}\right) \\
\text {dengan } \\
y_{j}{ }^{+}=\quad \max _{i j} y_{i j}, j i k a j=\text { benefit } \\
\min _{i} y_{i j}, j i k a j=\text { cost }
\end{gathered}
$$

Mencari solusi ideal positif yaitu dengan mencari nilai maksimal dari setiap kolom kriteria pada matriks $Y$ jika kriteria memiliki atribut benefit, tetapi jika kriteria memiliki atribut cost nilai yang dicari adalah nilai minimal.

Tabel 14. Solusi Ideal Positif

\begin{tabular}{|l|l|l|l|l|l|l|l|}
\hline \multirow{2}{*}{$\mathbf{A}^{+}$} & $\mathbf{C 1}$ & $\mathbf{C 2}$ & $\mathbf{C 3}$ & $\mathbf{C 4}$ & $\mathbf{C 5}$ & $\mathbf{C 6}$ & $\mathbf{C 7}$ \\
\cline { 2 - 8 } & 0,093 & 0,048 & 0,014 & 0,041 & 0,033 & 0,030 & 0,020 \\
\hline
\end{tabular}

b. Menentukan solusi ideal negative $\left(A^{-}\right)$

Untuk mencari solusi ideal negatif digunakan rumus di bawah ini.

$$
\begin{gathered}
A^{-}=\left(y 1^{-}, y 2^{-}, \cdots, y j^{-}\right) \\
\text {dengan } \\
y_{j}{ }^{-}={ }_{i} y_{i j}, j i k a j=\text { benefit } j \\
\max _{i} y_{i j}, j i k a j=\text { cost }
\end{gathered}
$$

Mencari solusi ideal negatif yaitu dengan mencari nilai minimal dari setiap kolom kriteria pada matriks $Y$ jika kriteria memiliki atribut benefit, tetapi jika kriteria memiliki atribut cost nilai yang dicari adalah nilai maksimal. 
Tabel 15. Solusi Ideal Negatif

\begin{tabular}{|l|l|l|l|l|l|l|l|}
\hline \multirow{2}{*}{$\mathbf{A}^{-}$} & $\mathbf{C 1}$ & $\mathbf{C 2}$ & $\mathbf{C 3}$ & $\mathbf{C 4}$ & $\mathbf{C 5}$ & $\mathbf{C 6}$ & $\mathbf{C 7}$ \\
\cline { 2 - 8 } & 0,028 & 0,024 & 0,047 & 0,008 & 0,010 & 0,009 & 0,007 \\
\hline
\end{tabular}

5. Menentukan jarak nilai terbobot setiap alternatif terhadap solusi ideal positif $\left(\mathrm{D}_{\mathrm{i}}^{+}\right)$dan solusi ideal negatif $\left(\mathrm{D}_{\mathrm{i}}^{-}\right)$.

a. Jarak solusi ideal positif $\left(\mathrm{D}_{\mathrm{i}}^{+}\right)$

Menentukan jarak antara nilai terbobot dengan solusi ideal positif dengan rumus di bawah ini.

$$
D_{i}^{+}=\prod_{i=1}^{n} y_{i j}-y_{i}^{+2}
$$

Maka didapatkan hasil sebagai berikut :

Tabel 16. Jarak Solusi Ideal Positif

\begin{tabular}{|l|c|}
\hline \multicolumn{1}{|c|}{ Nama } & $\mathbf{D}_{\mathbf{i}}^{+}$ \\
\hline Tatang Parjaman & 0,067 \\
\hline Kusnandi & 0,080 \\
\hline Awang Kustiawan & 0,027 \\
\hline Maman Herman & 0,031 \\
\hline
\end{tabular}

b. Jarak solusi ideal negatif $\left(\mathrm{D}_{\mathrm{i}}^{-}\right)$

Menentukan jarak antara nilai terbobot dengan solusi ideal negatif dengan rumus di bawah ini.

$$
D_{i}^{-}=\overline{\sum_{i=1}^{n} y_{i j}-y_{i}^{-}}
$$

Maka didapatkan hasil sebagai berikut .

Tabel 17. Jarak Solusi Ideal Negatif

\begin{tabular}{|l|l|}
\hline \multicolumn{1}{|c|}{ Nama } & \multicolumn{1}{c|}{$\mathbf{D}_{\mathbf{i}}^{-}$} \\
\hline Tatang Parjaman & 0,034 \\
\hline Kusnandi & 0,035 \\
\hline Awang Kustiawan & 0,085 \\
\hline Maman Herman & 0,084 \\
\hline
\end{tabular}

6. Menentukan nilai preferensi (V) untuk setiap alternatif. Nilai preferensi merupakan kedekatan suatu alternatif terhadap solusi ideal. Untuk mencari nilai proferensi menggunakan rumus di bawah ini.

Sehingga didapatkan hasil sebagai berikut :

$$
V=\frac{D i^{-}}{D i^{-}+D i^{+}}
$$

$$
\begin{aligned}
& V 1=\frac{0,034}{0,034+0,067}=0,716 \\
& V 2=\frac{0,035}{0,035+0,080}=0,113 \\
& V 3=\frac{0,085}{0,085+0,027}=0,565
\end{aligned}
$$


$V 4=\frac{0,084}{0,084+0,031}=0,639$

7. Perangkingan berdasarkan kedekatan setiap alternatif terhadap solusi ideal. Dari perhitungan sebelumnya didapatkan nilai akhir seperti pada tabel 18 :

Tabel 18. Nilai Preferensi

\begin{tabular}{|l|c|}
\hline Nama & Preferensi $\mathbf{( V )}$ \\
\hline Tatang Parjaman & 0,716 \\
\hline Kusnandi & 0,113 \\
\hline Awang Kustiawan & 0,565 \\
\hline Maman Herman & 0,639 \\
\hline
\end{tabular}

Maka apabila dilakukan perangkingan hasilnya dapat dilihat pada tabel 19 :

Tabel 19. Hasil Perangkingan Alternatif

\begin{tabular}{|c|l|l|l|}
\hline Ranking & Nama & Preferensi (V) & Keterangan \\
\hline 1 & Tatang Parjaman & 0,716 & Dosen Pembimbing \\
\hline 2 & Maman Herman & 0,639 & Dosen Pembimbing \\
\hline 3 & Awang Kustiawan & 0,565 & Bukan Dosen Pembimbing \\
\hline 4 & Kusnandi & 0,113 & Bukan Dosen Pembimbing \\
\hline
\end{tabular}

Dari tabel 19. Dapat kita simpulkan bahwa Dosen atas nama Tatang Parjaman dan Maman Herman adalah prioritas untuk menjadi Dosen Pembimbing di Program Pascasarjana Universitas Galuh Ciamis.

\subsection{Perancangan Sistem}

Diagram use case digunakan untuk menggambarkan pengguna aplikasi dan perilaku pengguna (yang sering dinamakan sebagai aktor) terhadap aplikasi. Diagram use case dalam sistem pendukung keputusan penentuan dosen pembimbing dan bimbingan thesis secara online dapat dilihat pada gambar 3 .

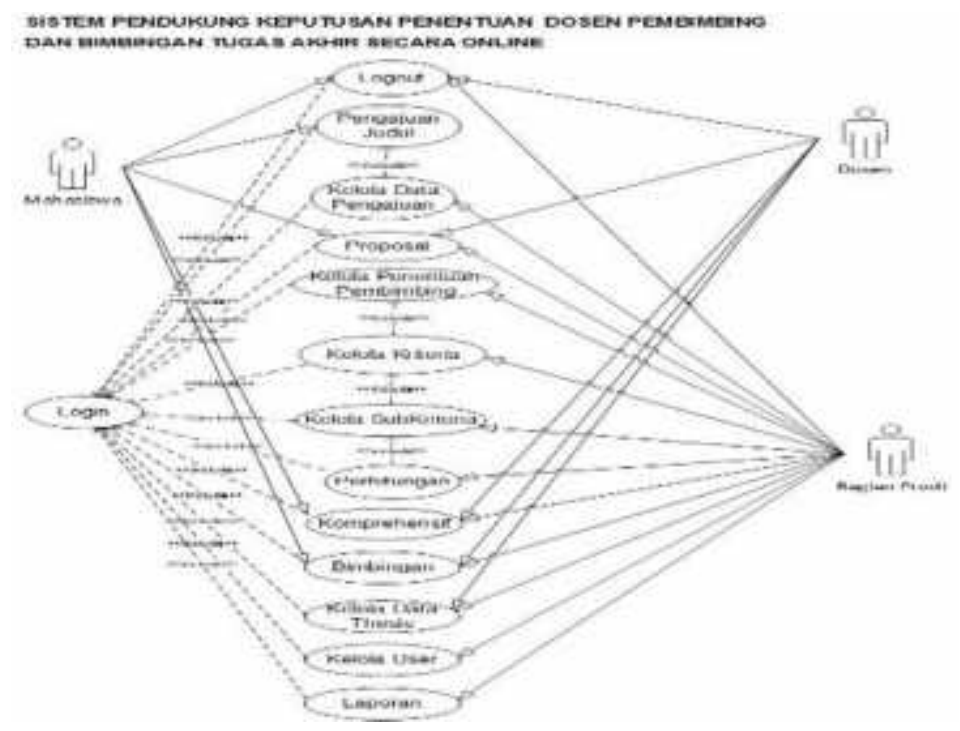

Gambar 3. Usecase Diagram 


\subsection{Perancangan Basis Data}

Entity relationship diagram untuk sistem pendukung keputusan penentuan dosen pembimbing dan bimbingan thesis secara online adalah sebagai berikut :

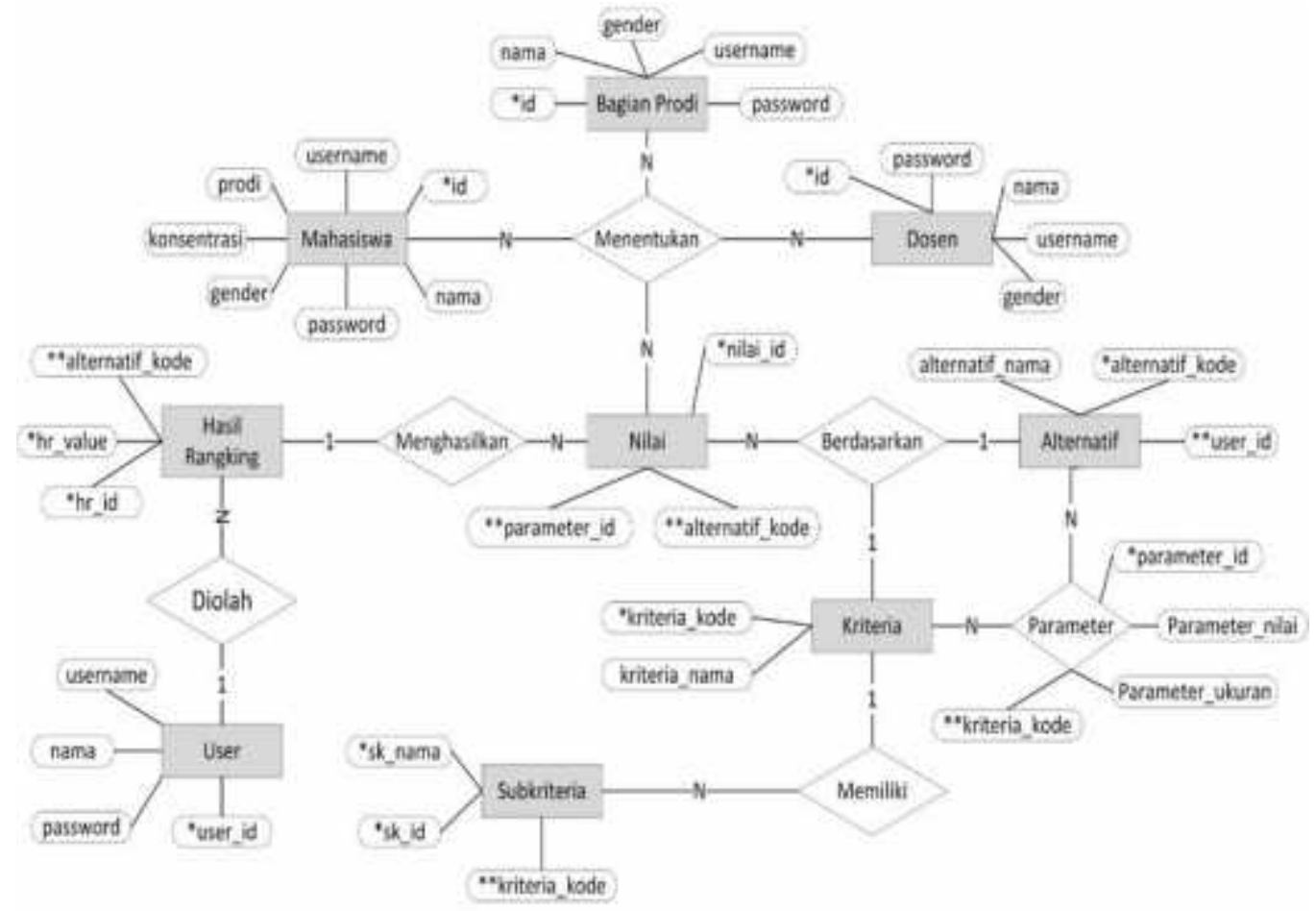

Gambar 4. Entity Relationship Diagram

\subsection{Implementasi Sistem}

Implementasi sistem merupakan prosedur yang dilakukan dalam menyelesaikan desain sistem yang telah disetujui, untuk menguji, menginstall, dan memulai sistem baru atau sistem yang diperbaiki untuk menggantikan sistem yang lama, sedangkan tahap implementasi sistem merupakan tahap meletakan sistem agar sistem siap untuk dioperasikan. Adapun gambaran umum program yang diajukan adalah sebagai berikut :

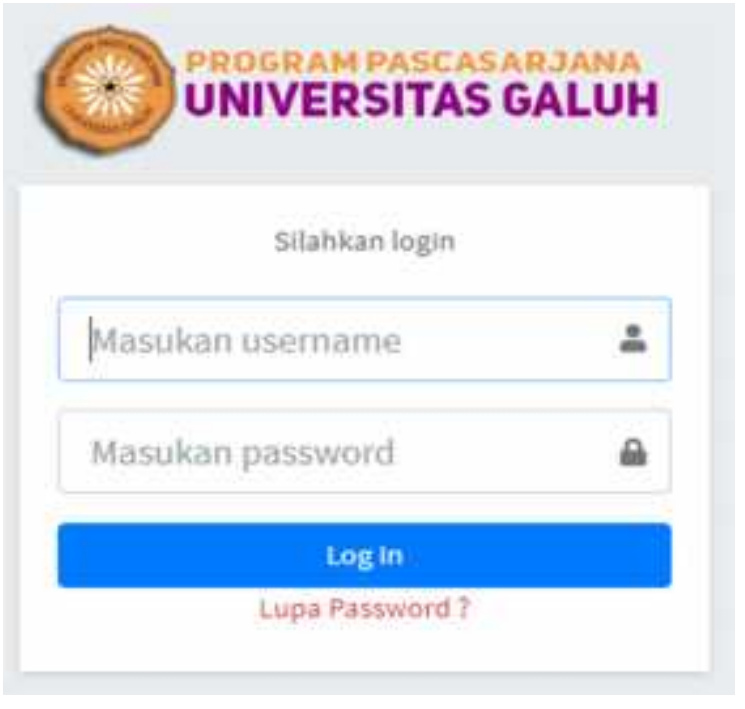

Gambar 5. Form Halaman Login

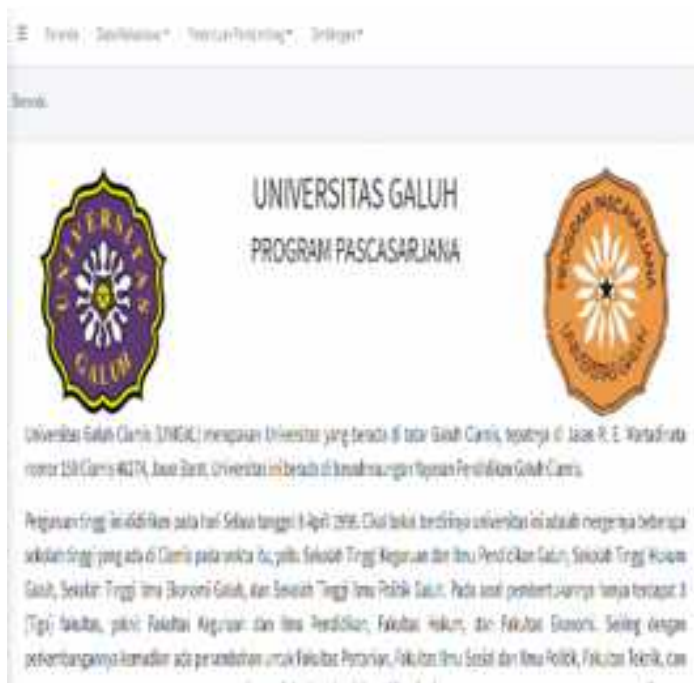

Gambar 6. Halaman Utama 


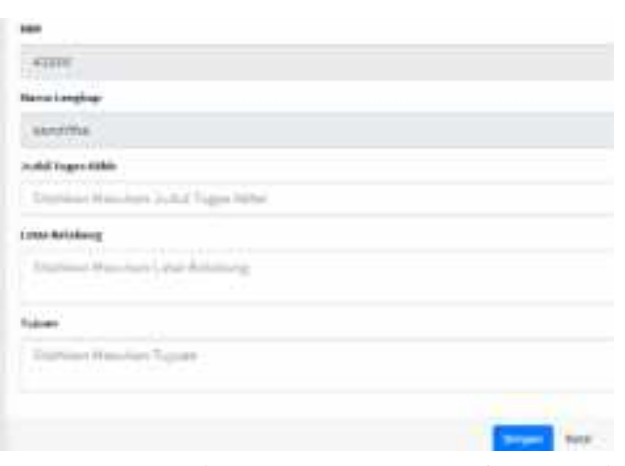

Gambar 7. Form Pengajuan Judul Pembimbing

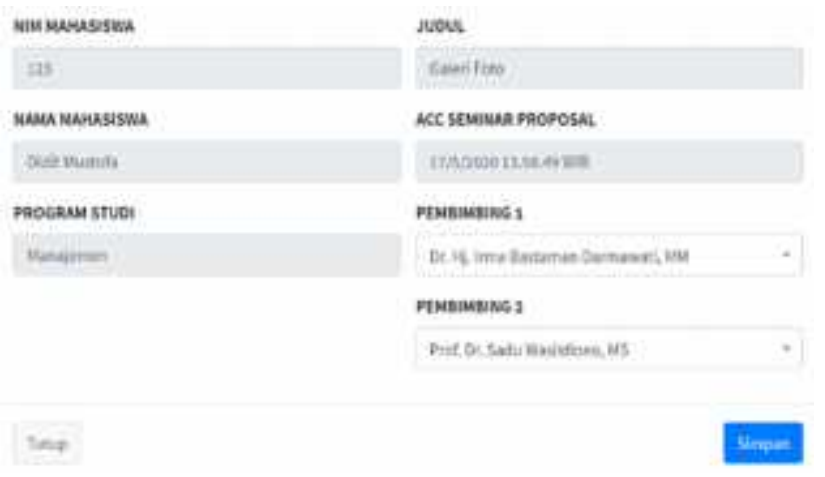

Gambar 8. Form Penentuan

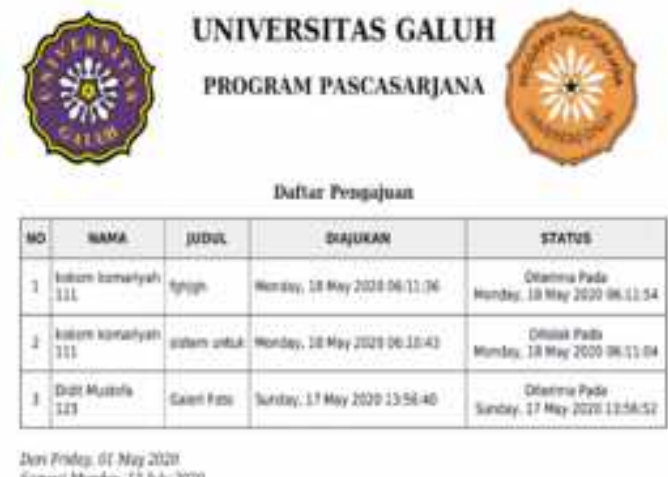

Ben Roder of Nar ation

Gambar 9. Laporan Pengajuan Judul Pembimbing

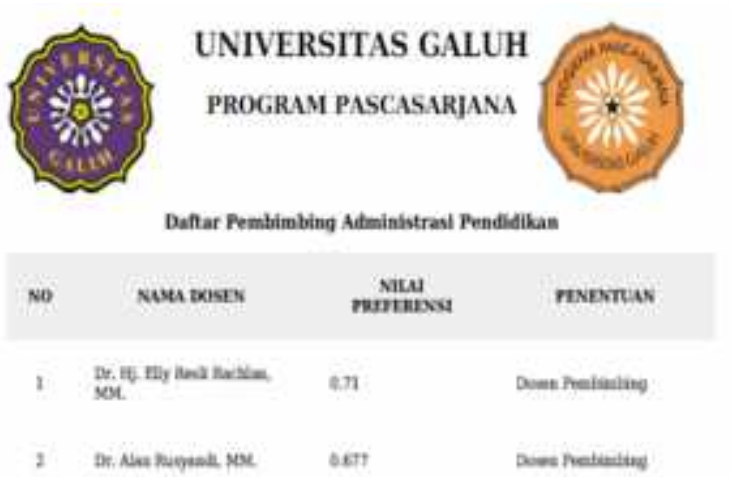

Gambar 10. Laporan Penentuan

\section{KESIMPULAN}

Setelah melakukan penelitian, pembahasan, dan pengujian mengenai sistem pendukung keputusan Penentuan dosen pembimbing dan bimbingan thesis secara online, dapat diambil kesimpulan sebagai berikut :

1. Sistem pendukung keputusan dalam Penentuan dosen pembimbing dan bimbingan thesis secara online ini dibangun berbasis web dan secara online sehingga proses dalam menentukan pembimbing dan bimbingan secara online menjadi lebih cepat karena Mahasiswa hanya tinggal mengunggah dokumen bimbingan per-Bab melalui aplikasi yang terkoneksi dengan internet.

2. Dengan adanya Sistem pendukung keputusan dalam Penentuan dosen pembimbing dalam indikator penilaian kriteria yang digunakan dapat dihitung menggunakan aplikasi pendukung keputusan dengan menerapkan metode Analytical Hierarchy Process (AHP) dan Technique For Order Preference By Similarity To Ideal Solution (TOPSIS) dimana data penilaian dalam menentukan pembimbing diproses menggunakan perhitungan tertentu dan menghasilkan suatu nilai kelayakan. Dari nilai tersebut dapat dilihat penentuan pembimbing lebih optimal serta meminimalisir kurang tepatnya keputusan, sehingga proses penilaian dapat terhindar dari subjektifitas. 
3. Aplikasi sistem pendukung keputusan Penentuan dosen pembimbing dan bimbingan thesis secara online dalam proses pembuatan laporan dapat membantu mahasiswa dan Dosen dalam riwayat bimbingan dan dapat membantu Bagian Prodi membuat laporan yang lebih efektif dan lebih cepat karena sudah terautomatisasi.

\section{SARAN}

Berdasarkan penelitian yang dilakukan di Universitas Galuh Ciamis pada Program Pascasarjana, penyusun memberikan beberapa saran, dengan harapan dapat menjadi masukan bagi pihak Bagian Prodi dan bagi pengembangan penelitian di kemudian hari, diantaranya sebagai berikut :

1. Untuk penelitian selanjutnya, peneliti menyarankan adanya kombinasi metode lainnya selain metode Analytical Hierarchy Process (AHP) dan Technique For Order Preference By Similarity To Ideal Solution (TOPSIS) untuk mengambil keputusan sehingga dapat meningkatkan akurasi hasil penelitian pada obyek penelitian yang lain.

2. Diharapkan adanya pengembangan terhadap program aplikasi ini untuk meningkatkan efisiensi kegunaannya dan melengkapi kekurangan yang ada.

\section{DAFTAR PUSTAKA}

[1] [Tata Sutabri. 2012. "Konsep Sistem Informasi” Yogyakarta: C.V Andi Offset.

[2] Ahmad Abdul Chamid. 2017. "Kombinasi Metode AHP dan TOPSIS Pada Sistem Pendukung Keputusan,” Prosidang SNATIF Ke-4, no. ISBN: 978-602-1180-50-1, pp

[3] I. Binanto, "Analisa Metode Classic Life Cycle (Waterfall) Untuk Pengembangan Perangkat Lunak Multimedia,” Teknik Informatika Universitas Sanata Dharma, pp. 1-7, 2015

[4] A. S. R. d. M. Shalahuddin, "Rekayasa Perangkat Lunak Terstruktur Dan Berorientasi Objek" Bandung: Informatika Bandung, 2013

[5] Kusrini, M.Kom. 2018. "Konsep dan Aplikasi Sistem Pendukung Keputusan.” Yogyakarta: C.V Andi Offset. 